\title{
Disease Resistance to Multiple Fungal and Oomycete Pathogens Evaluated Using a Recombinant Inbred Line Population in Pepper
}

\author{
R. P. Naegele, L. L. Granke, J. Fry, T. A. Hill, H. Ashrafi, A. Van Deynze, and M. K. Hausbeck†
}

First author: Research Horticulturalist, United States Department of Agriculture-Agricultural Research Service Crop Diseases, Pests and Genetics Research Unit, Parlier, CA 93720; second author: Associate Research Scientist, Dow Agrosciences, Indianapolis, IN 46268; third author: Former Graduate Research Assistant, Department of Plant, Soil and Microbial Sciences, Michigan State University, East Lansing, MI 48824; fourth author: Senior Research Associate, Department of Plant Sciences, University of California, Davis 95616; fifth author: Assistant Professor, North Carolina State University, Raleigh 27695-7550; sixth author: Director of Research, Seed Biotechnology Center, University of California, Davis; and seventh author: Professor, Department of Plant, Soil, and Microbial Sciences, Michigan State University, East Lansing 48824.

Accepted for publication 24 July 2017.

\begin{abstract}
Incorporating disease resistance into cultivars is a primary focus of modern breeding programs. Resistance to pathogens is often introgressed from landrace or wild individuals with poor fruit quality into commercialquality cultivars. Sites of multiple disease resistance (MDR) are regions or "hot spots" of the genome with closely linked genes for resistance to different pathogens that could enable rapid incorporation of resistance. An $\mathrm{F}_{2}$-derived $\mathrm{F}_{6}$ recombinant inbred line population from a cross between 'Criollo de Morelos 334' (CMM334) and 'Early Jalapeno' was evaluated in inoculated fruit studies for susceptibility to oomycete and fungal pathogens: Phytophthora capsici, P. nicotianae, Botrytis cinerea, Fusarium oxysporum, F. solani, Sclerotinia sclerotiorum, Alternaria spp.,

susceptibility were identified among lines for each of the pathogens evaluated. $P$. capsici was the most virulent pathogen, while $R$. oryzae and one Sclerotinia isolate were the least virulent. Quantitative trait loci associated with resistance were identified for Alternaria spp. and S. sclerotiorum. Positive correlations in disease incidence were detected between Alternaria spp. and F. oxysporum, F. solani, and C. acutatum, as well as between C. acutatum and Botrytis spp., F. oxysporum, F. solani, and P. capsici. No sites of MDR were identified for pathogens tested; however, positive correlations in disease incidence were detected among pathogens suggesting there may be genetic linkage among resistance genes in CM334 and Early Jalapeno.
\end{abstract} Rhizopus oryzae, $R$. stolonifer, and Colletotrichum acutatum. All isolates evaluated were virulent on pepper. Significant differences in disease
Additional keywords: Capsicum annuum, host resistance.
Pepper (Capsicum annuum) is the third most important solanaceous crop in the United States and the fourth most important in the world. In the United States, approximately $\$ 78$ million of bell and chili pepper fruit were exported in 2016 (USDA Economic Research Service 2017). Worldwide, nearly 200 million and 33 million tons of green and dry pepper fruit, respectively, are produced annually. Plant pathogens (bacterial, fungal, and oomycete) cost pepper growers millions of dollars annually through indirect and direct expenses, including pesticide and antibiotic use, increased labor, and reduced yields and quality. Resistant varieties and improved cultural practices have been highly successful at reducing the prevalence of diseases caused by some bacterial pathogens in the United States (Pernezny et al. 2003). Pre- and postharvest diseases of pepper caused by fungal and oomycete pathogens can still result in devastating losses for individual growers (Pernezny et al. 2003). Common diseases of pepper include major and minor fungal diseases such as white mold (Sclerotinia spp.), Fusarium wilt and rot (Fusarium spp.), anthracnose rot (Colletotrichum spp.), Rhizopus rot (Rhizopus spp.), gray mold (Botrytis cinerea), and Alternaria rot (Alternaria spp.); and major oomycete diseases such as Phytophthora rot (Phytophthora spp.) (Anand et al. 2009; Kamara et al. 2016; Le et al. 2013; Pernezny et al. 2003; Singh et al. 2014; Zitter 2000). Major diseases caused by pathogens such as Phytophthora capsici can result in complete crop failure when left unmanaged (Granke et al. 2012). Minor pathogens cause fewer losses but still require chemical or cultural practices to

†Corresponding author: M. K. Hausbeck; E-mail: hausbec1@msu.edu

This article is in the public domain and not copyrightable. It may be freely reprinted with customary crediting of the source. The American Phytopathological Society, 2017. mitigate losses (Frans et al. in press; Tzortzakis and Chrysargyris 2017). The impact of these individual pathogens varies greatly among regions but each is responsible for pre- and postharvest loss of pepper.

Host resistance is frequently incorporated into cultivated species from related wild and weedy species. These sources often have undesirable commercial qualities such as indeterminate growth, poor fruit quality, uneven ripening, and small fruit size (Acquaah 2012; Khan et al. 2014). Resistance from wild and landrace pepper has been used to incorporate Phytophthora root rot, bacterial spot, Tobacco etch virus, Cucumber mosaic virus, and Verticillium wilt resistance into commercial varieties (Hibberd and Gillespie 1982; Hibberd et al. 1987; Holdsworth and Mazourek 2015; Padgett et al. 1990). To incorporate only traits of interest, plants must undergo intensive phenotypic selection to minimize negative attributes. Studies have shown that disease resistance can have linkage or pleiotropic effects on commercial traits such as yield or fruit shape (Cheng 2014; Haggard et al. 2013; Naegele et al. 2014). In addition to poor fruitquality traits, it is possible for undesirable disease susceptibility traits to be transferred from the wild background into the cultivated pepper.

In pepper, 'Criollo de Morelos 334' (CM334), a landrace from Mexico, is the main source of $P$. capsici resistance used for developing commercial cultivars. Resistance to $P$. capsici is one of the most genetically mapped pathosystems in pepper. For fruit, root, and foliar resistance, the major quantitative trait loci (QTL) were localized on pepper chromosome 5 (Mallard et al. 2013; Naegele et al. 2014; Ogundiwin et al. 2005; Rehrig et al. 2014; Sy et al. 2008; Walker and Bosland 1999). Other Phytophthora spp. such as $P$. nicotianae can also infect pepper, and QTL for root rot resistance have been identified on pepper chromosomes 3,9, and 11 (Bonnet et al. 2007). Resistance to anthracnose, caused by Colletotrichum 
gleosporoides and $C$. capsici, has also been mapped in pepper. One to three QTL were identified, depending on the Colletotrichum sp. (Kim et al. 2008; Voorrips et al. 2004). A single recessive gene was determined to control resistance in the pepper species Capsicum chinense. In these anthracnose studies, QTL were identified though not associated with chromosomes. However, in a recent study, resistance QTL for Colletotrichum acutatum were identified on pepper chromosome 5 (Sun et al. 2015).

In sunflower, soybean, and rapeseed, QTL for resistance to Sclerotinia sclerotiorum have been identified, suggesting that it is a multigenic resistance (Arahana et al. 2001; Mestries et al. 1998; Micic et al. 2005; Zhao and Meng 2002). Evaluation of pepper cultivars and germplasm identified sources of resistance to $S$. sclerotiorum but, to date, no QTL studies have been performed (Yanar and Miller 2003). Resistance to Botrytis spp. has been identified in tomato on chromosomes 3, 4, and 9 (Finkers et al. 2007a). However, no studies have identified QTL for resistance to Botrytis spp. in pepper. Similarly, no information on QTL contributing to resistance to Alternaria spp., Fusarium oxysporum, Rhizopus stolonifer, $R$. oryzae, or F. solani is currently available for pepper.

As genetic maps and genomic resources have advanced, clusters or "hot spots" of traits have been identified in plants (Frary et al. 2014; Quirin et al. 2012; Thabuis et al. 2003). In pepper, chromosome 5 has been identified as a hot spot for Phytophthora spp. resistance, as well as resistance to $C$. acutatum. Among potato, tomato, and pepper, Grube et al. (2000) demonstrated that regions of shared resistance exist in the family Solanaceae. In tomato and potato, colocalization of QTL for $P$. infestans have been identified between the two species, suggesting that homologous regions of resistance exist among solanaceous species (Brouwer et al. 2004). Few colocalization studies on disease resistance have been done in the family Solanaceae, and no studies have examined resistance across fungal and oomycete pathogens. In pepper, colocalization among virus resistance QTL were determined, suggesting that regions of multipathogen resistance exist, and that the viruses were controlled by the similar genetic regions (Caranta et al. 1997). In grasses, regions of multiple disease resistance (MDR) have been identified for corn (southern leaf blight, gray leaf spot, and northern leaf blight) and rye (gray leaf spot, crown rust, leaf spot, and stem rust) (Jo et al. 2008; Zwonitzer et al. 2010). When present, identifying regions of MDR can improve our understanding of disease resistance and facilitate breeding of commercial cultivars with enhanced resistance.

The objectives of this research were to (i) evaluate resistance, (ii) evaluate likelihood of infection in pepper to oomycete and fungal pathogens, and (iii) identify QTL associated with host resistance.

\section{MATERIALS AND METHODS}

Plant material and isolate selection. A set of 63 recombinant inbred lines ( $\mathrm{RIL})\left(\mathrm{an}_{2} \mathrm{~F}_{2}\right.$-derived $\left.\mathrm{F}_{6}\right)$ was used for all evaluations. The RIL, developed by Dr. Paul Bosland, were derived from hybridization of 'Early Jalapeno' (susceptible to P. capsici) and CM334 (resistant to P. capsici) to study resistance to Phytophthora root rot (Walker and Bosland 1999). Plants were grown in a glasshouse at the Michigan State University Plant Sciences Greenhouses in East Lansing in 1-gal. pots containing Suremix Perlite (Michigan Grower Products, Inc., Galesburg, MI).

In total, nine fungal and five oomycete isolates were collected from diseased plant material in Michigan or were donated by colleagues (Table 1). Isolates were inoculated onto and reisolated from jalapeño pepper fruit prior to fruit screens to ensure pathogenicity and promote virulence. Fungal isolates were maintained on potato dextrose agar (PDA) (39 $\mathrm{g}$ of PDA and 1 liter of distilled water) and grown under constant fluorescent light at room temperature. Oomycete isolates were maintained on unclarified V8 agar (UCV8) (16 g of agar, $30 \mathrm{mM}$ $\mathrm{CaCO}_{3}, 160 \mathrm{ml}$ of unfiltered V8 juice, and $840 \mathrm{ml}$ of distilled water) and grown under constant fluorescent light at room temperature. $P$. capsici isolates were previously evaluated on the pepper population (Naegele et al. 2014).

Fruit inoculations and evaluations. Immature green pepper fruit ( 2 to $4 \mathrm{~cm}$ in length) were surface disinfested for $5 \mathrm{~min}$ in a $10 \%$ sodium hypochlorite solution, rinsed with distilled water, and air dried. Pepper fruit were inoculated with a single isolate or negative control and incubated in clear polystyrene boxes with lids (23 by 10 by $32 \mathrm{~cm}$; Potomac Display, Hampstead, MD), which contained wet paper towels to maintain high relative humidity. Pepper fruit were incubated under constant fluorescent lighting at room temperature (approximately $25 \pm 2^{\circ} \mathrm{C}$ ) for 1 week, except for pepper fruit inoculated with Rhizopus spp., which were incubated for 4 days, and pepper fruit inoculated with $P$. nicotianae or $P$. capsici, which were incubated for 5 days. At the end of the incubation period, pepper fruit were rated for symptoms of fruit rot and pathogen sporulation on the fruit. Fruit that showed symptoms of disease or pathogen signs were rated as susceptible (=1) and fruit showing no symptoms or signs at the end of the incubation period were rated as resistant $(=0)$. Five replicate fruit were used for each experiment and the experiment was conducted two times for each fungal pathogen. Isolations were performed on symptomatic and asymptomatic fruit to confirm the presence or absence of the pathogen if no active sporulation was observed. For isolations, the skin was peeled back using a scalpel, and three 1-mm sections of pepper fruit were plated onto a single plate of PDA for fungi or UCV8 amended with ampicillin and rifampicin for oomycetes and grown under constant fluorescent light in the lab at $25^{\circ} \mathrm{C}$. The

TABLE 1. Fungal and oomycete isolates used in this study ${ }^{\mathrm{z}}$

\begin{tabular}{llll}
\hline Fungal species & Host of origin & Identifier & Source \\
\hline Alternaria spp. & Eggplant & None & L. L. Granke \\
Botrytis cinerea & Geranium & None & B. R. Harlan \\
Colletotrichum acutatum & Tomato & None & L. M. Rodriguez-Salamanca \\
Fusarium oxysporum & Potato & None & E. Gachango \\
F. solani & Potato & None & E. Gachango \\
Sclerotinia sclerotiorum & Soil & Decatur & J. J. Hao \\
S. sclerotiorum & Soybean & Clarksville & J. J. Hao \\
Rhizopus oryzae & Sugarbeet & Rp08-1 & L. E. Hanson \\
R. stolonifer & Sugarbeet & Rp07-1 & L. Hanson \\
Phytophthora capsici & Pepper & 12889 & M. K. Hausbeck \\
P. capsici & Cucumber & OP97 & M. K. Hausbeck \\
$P$. capsici & Bean & 13709 & M. K. Hausbeck \\
$P$ nicotianae & Water & 1006 & C. D. Smart \\
$P$ nicotianae & Water & 1007 & C. D. Smart \\
\hline
\end{tabular}

${ }^{\mathrm{z}}$ All isolates were collected from naturally infected plant material or soil in Michigan or surface water in New York by the authors or colleagues at Michigan State University and Cornell University. 
pathogen was confirmed based on morphological characteristics. The experiment was a complete randomized design blocked by isolate. Due to limited fruit, three replicate fruit were used for each experiment and the experiment was conducted three times for each $P$. nicotianae species.

For Alternaria spp. and B. cinerea, a 7-day-old culture on PDA was flooded with sterile distilled water with $0.1 \%$ Tween 80 . The resulting suspension was adjusted to $10^{5} \mathrm{conidia} / \mathrm{ml}$ for Alternaria spp. and $10^{6}$ conidia $/ \mathrm{ml}$ for $B$. cinerea. For Alternaria spp. inoculations, each fruit was wounded in the center of the fruit using a pipette tip (200- $\mu$ l size), and $10 \mu \mathrm{l}$ of spore suspension or double-distilled (dd) $\mathrm{H}_{2} \mathrm{O}$ (negative control) was pipetted directly over the wound. For B. cinerea inoculation, each pepper was gently wounded by lightly passing a scalpel across the stem scar, and $50 \mu \mathrm{l}$ of spore suspension or $\mathrm{ddH}_{2} \mathrm{O}$ (negative control) was pipetted onto the wounded stem scar.

For $C$. acutatum, F. solani, and F. oxysporum, sterile distilled water was added to a 14-day-old culture on PDA. The resulting spore suspension was adjusted to $5 \times 10^{6}$ conidia/ml for $C$. acutatum and $10^{6}$ conidia/ml for Fusarium spp. For C. acutatum and F. oxysporum, fruit were inoculated in the same manner as described above for Alternaria spp. For F. solani, fruit were wounded as described above for $B$. cinerea, and $10 \mu \mathrm{l}$ of spore suspension or $\mathrm{ddH}_{2} \mathrm{O}$ (negative control) was pipetted onto the wounded stem scar.

For Rhizopus spp., a cork borer was used to remove a 7-mmdiameter agar plug from a 7-day-old culture growing on PDA. The agar plug was placed in the center of the pepper fruit. For S. sclerotiorum and Phytophthora spp., fruit were inoculated as described above for Rhizopus spp., except each PDA or UCV8 agar plug was covered with a 12-mm-diameter screw cap (Axygen Scientific, Union City, CA) that was affixed to the fruit surface using petroleum jelly. Negative controls (agar only) were included and inoculated as described above.

Genotyping. Each pepper line had previously been genotyped using single-position polymorphism detection coupled with the Affymetrix GeneChip array developed for pepper (Hill et al. 2013). The chip consisted of 6,473,556 genomic tiling probes representing 31,196 unigene sequences, with a 2-bp overlap for each probe (Hill et al. 2013).

Data analysis. Disease incidence (number of fruit displaying symptoms out of the total number of fruit) was calculated for each line and pathogen. Significant differences were detected among lines with the PROC LOGISTIC procedure in SAS statistical software (v9.3; SAS Institute, Cary, NC) using a reference parameter and the descending option. Pathogens were compared with $R$. oryzae and lines were compared with the cultivated parent Early Jalapeno. Mean infection values of each pathogen were calculated using a random effects model in PROC GLIMMIX. Then, the odds ratio of a line being infected by a particular pathogen, as compared with the average infection rate among lines by that pathogen, were obtained for each line using Wald square limits at a 95\% confidence interval. This provided a measure of the risk of infection of a line by a particular pathogen, as compared with the average infection rate for that pathogen. Linkage analyses were performed using R/qtl software (Broman et al. 2003; R Development Core Team 2012) in R v3.0 on the pepper genetic map previously published and evaluated for quality control (Hill et al. 2013; Naegele et al. 2014). QTL were mapped using incidence data and disease threshold data. When mapping disease threshold, if disease incidence was $\geq 50 \%$ based on the total number of pepper fruit evaluated, the individual line would receive a disease score of 1 and, if $<50 \%$, the line would receive a disease score of 0 . Missing data were filled using the imputation method for incidence data and entropy method for disease threshold data. Putative QTL were detected using the scanone method implemented in $\mathrm{R}$ with the binary model for disease threshold data with the EM algorithm method. For disease incidence, QTL were detected using the multiple imputation method. Significance of loci was determined using logarithm of odds (LOD) thresholds calculated from 1,000 permutations for each pathogen. Correlations among pathogens in disease incidence were analyzed using the PROC CORR feature implemented in SAS.

\section{RESULTS}

In the CM334 $\times$ Early Jalapeno population, disease resistance for each pathogen evaluated varied among lines, and significant differences were detected (Fig. 1). Of the eight fungal pathogen species evaluated, a Sclerotinia sp. (Decatur isolate) and $R$. oryzae caused the least amount of disease on pepper fruit. Infection by $P$. capsici isolates resulted in the greatest number of lines that had a significantly higher likelihood of disease than the population mean.

The odds ratio (the odds that disease will occur given exposure to a particular variable) for pathogen $(P=0.0037)$ and the interaction between line and pathogen $(P=0.0123)$ were both significant. CM334 had a reduced incidence of fruit rot caused by $P$. capsici and $P$. nicotianae, whereas Early Jalapeno had high disease incidence, consistent with previous studies (Table 2) (Naegele et al. 2014; Sy et al. 2008). However, Early Jalapeno had low disease incidence when inoculated with Alternaria spp., C. acutatum, F. solani, R. stolonifer, and $R$. oryzae, whereas CM334 was susceptible to these pathogens (Fig. 2). Neither parent was susceptible to Sclerotinia spp. (Clarksville or Decatur isolates), although resistance segregated within the progeny and four lines had disease incidence $\geq 50 \%$. In addition, both parents were moderately susceptible to Botrytis spp. and $F$. oxysporum but the progeny segregated for resistance. CM334, although resistant to Phytophthora spp., was not significantly more resistant to other pathogens evaluated in this study compared with the cultivated parent Early Jalapeno. In some instances, CM334 had increased susceptibility compared with Early Jalapeno.

When pepper lines were compared across all pathogens, C, M, K, $\mathrm{B}, \mathrm{AAS}$, and AA had the greatest number of pathogens $(\geq 5)$ to which they significantly differed in susceptibility compared with the population mean. When individual pathogens were evaluated, large differences were detected in line susceptibility and mean disease incidence.

When inoculated with a Sclerotinia sp. (Decatur isolate), the two pepper parents were not different and had low disease incidence (0 to $10 \%)$. Infection within the progeny remained low, with line AF having the highest incidence $(60 \%)$ and 22 lines exhibiting no symptoms (Table 2 ). The population mean was $16.5 \pm 16.3 \%$. The likelihood of infection was significantly more probable for only two lines $(\mathrm{G}$ and $\mathrm{N}$ ) as compared with the population average. The LOD threshold for disease incidence was determined to be 3.03 (10\%) and $3.33(5 \%)$. A significant QTL was identified on chromosome 11 (CAPS_CONTIG.6117) at position 90 (LOD = 3.38). The QTL explained $22 \%$ of the variation observed. When disease incidence was converted to a disease threshold, no QTL were detected above the $10 \%$ LOD threshold (1.44). The genetic map used to identify QTL in the pepper population was previously described in detail (Hill et al. 2013).

When inoculated with the Sclerotinia isolate from Clarksville, the two pepper parents were not significantly different in the likelihood of infection, and disease incidence was low (10 and $20 \%$ ). Likelihood of infection was significantly greater in four lines compared with the population average. Line AAB had the highest incidence (80\%) when infected with the Sclerotinia isolate (Clarksville), whereas 14 lines did not become diseased (Table 2). However, multiple lines with low to moderate disease incidence when inoculated with a Sclerotinia sp. (Decatur) had high disease incidence when inoculated with isolate Clarksville or vice versa. The population mean was $22 \pm 20 \%$. No QTL were observed for disease incidence above the 10\% LOD threshold (2.92).

When inoculated with $R$. oryzae or $R$. stolonifer, the two pepper parents differed in disease incidence, with $10 \%$ (Early Jalapeno) and $100 \%$ (CM334) of fruit infected. Line differences were detected between Rhizopus spp., suggesting that resistance is species, if not isolate, specific. For $R$. oryzae, the likelihood of infection was higher for seven lines than the population average (Table 3). Line AC had the highest disease incidence $(90 \%)$ when infected with $R$. oryzae, whereas 35 lines did not become diseased (Table 2). The population 
mean was $10.3 \pm 16.9 \%$. The LOD threshold for pathogen incidence was determined to be $2.40(10 \%)$ and $2.66(5 \%)$. No QTL were observed for disease incidence above the LOD threshold for disease incidence or disease threshold.

Line AU had the highest incidence (100\%) when infected with $R$. stolonifer, whereas 13 lines did not display disease symptoms (Table 2). Likelihood of infection was significantly increased for lines J, AG, AR, AT, AU, AZ, and CM334 compared with the population average. The population mean was $24.6 \pm 22.6 \%$. The LOD threshold for pathogen incidence was determined to be $2.81(10 \%)$ and $3.10(5 \%)$. No QTL were observed for disease incidence above the LOD threshold.

When inoculated with $F$. oxysporum, neither of the pepper parents had a high disease incidence (10\% Early Jalapeno and 30\% CM334). Seven lines had a significantly greater likelihood of infection compared with the population average (Table 3 ). Line D had the highest incidence (100\%) when infected with F. oxysporum, whereas 12 lines did not become diseased (Table 2). The population mean was $25.5 \pm 23.5 \%$. LOD threshold for disease incidence was determined to be $2.94(10 \%)$ and $3.20(5 \%)$. No QTL were observed for disease incidence or disease threshold above the LOD threshold.

When inoculated with $F$. solani, the two pepper parents differed in the likelihood of infection and varied in disease incidence, with $0 \%$ for Early Jalapeno and 70\% for CM334. The likelihood of infection was significantly greater than the population average for eight lines and significantly less for eight (Table 3). Lines AM and AAE had the highest incidence $(100 \%)$ when infected with $F$. solani, whereas six lines had no disease incidence (Table 2). The population mean was $42.6 \pm 29.1 \%$. The LOD threshold for disease incidence was determined to be $3.04(10 \%)$ and $3.45(5 \%)$. No QTL were observed for disease incidence or disease threshold above the LOD threshold.

When inoculated with $C$. acutatum, the two pepper parents differed in disease incidence (70\% for CM334 and 20\% for Early Jalapeno). When compared with the population average, 7 lines had a significantly higher likelihood of infection and 10 lines had a significantly lower incidence (Table 3). Line AP had the highest incidence $(100 \%)$ when infected with $C$. acutatum, whereas nine lines did not become diseased (Table 2). The population mean was
$40.9 \pm 28.7 \%$. The LOD threshold was determined to be $3.02(10 \%)$ and $3.38(5 \%)$. No QTL were observed for disease incidence or disease threshold above the LOD threshold.

When inoculated with Botrytis spp., the two pepper parents differed in the likelihood of infection compared with the population average, despite minimal differences in incidence (50\% for CM334 and 60\% for Early Jalapeno). When compared with the population average, 8 lines had a significantly higher likelihood of infection and 10 had a lower likelihood (Table 2). Lines $\mathrm{C}$ and D had the highest incidence (100\%) when infected with Botrytis spp. while line J had the lowest disease incidence (10\%) (Table 2). The population mean was $60.8 \pm$ $20.1 \%$. The LOD threshold was determined to be $2.93(10 \%)$ and $3.38(5 \%)$ for disease incidence. Only 7 of the 63 lines evaluated had a disease incidence $\leq 30 \%$. No QTL were observed for disease incidence or disease threshold above the LOD threshold with visual separation of the disease phenotype.

When inoculated with Alternaria spp., the two pepper parents were different in disease incidence ( $0 \%$ for Early Jalapeno and $90 \%$ for CM334). Only two lines (AAC and J) had a significantly lower likelihood of infection than the population average. Seven lines had $100 \%$ disease incidence when infected with Alternaria spp. whereas lines AAG, AS, AP, AA, J, and I had no disease (Table 2). The population mean was $51.6 \pm 30.1 \%$. The LOD threshold was determined to be $3.11(10 \%)$ and $3.52(5 \%)$. A single QTL was detected on chromosome $2(\mathrm{LOD}=5.92, P<0.001)$ located at position 63 centimorgans (cM) (marker ANOK.CO776125). When disease incidence was converted to a disease threshold, the LOD threshold was $2.95(10 \%)$ and $3.24(5 \%)$. The marker identified for disease incidence was redetected (Table 4).

When inoculated with P. nicotianae (isolate 1006), the two pepper parents differed in disease incidence (38\% CM334 and 63\% Early Jalapeno). Only line $\mathrm{N}$ had a significantly higher likelihood of infection compared with the population mean. Two lines had $100 \%$ disease incidence when infected with $P$. nicotianae (1006), whereas lines $\mathrm{AAB}, \mathrm{AQ}$, and $\mathrm{AX}$ had no disease symptoms (Table 2). The population mean incidence was $49.4 \pm 25.8 \%$. The LOD threshold was determined to be $2.98(10 \%)$ and $3.32(5 \%)$. No QTL were

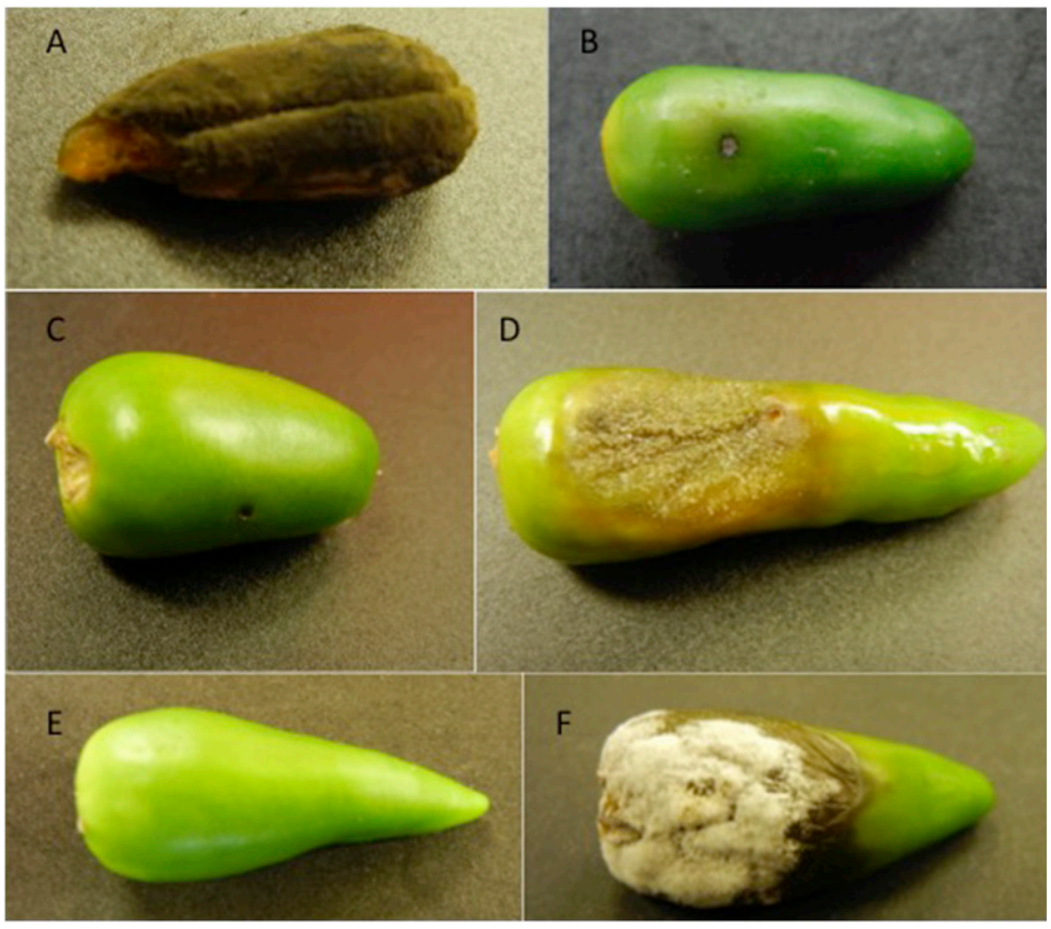

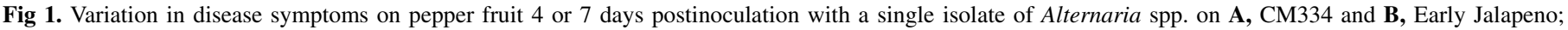
Colletotrichum acutatum on C, Early Jalapeno and D, AZ; or Fusarium solani on E, AAK and F, AF. 


\begin{tabular}{|c|c|c|c|c|c|c|c|c|c|c|c|c|c|c|}
\hline \multirow[b]{3}{*}{ Line } & \multicolumn{14}{|c|}{ Pathogen } \\
\hline & \multirow[b]{2}{*}{$A l t^{\mathrm{q}}$} & \multirow[b]{2}{*}{$B o t^{\mathrm{r}}$} & \multirow[b]{2}{*}{$\mathrm{Col}^{\mathrm{s}}$} & \multirow[b]{2}{*}{$F . s^{\mathrm{t}}$} & \multirow[b]{2}{*}{$F . o^{\mathrm{u}}$} & \multirow[b]{2}{*}{$R s o^{\mathrm{v}}$} & & Scler & ia $\mathrm{sp}$. & & hthora & & P. $n$ & anae \\
\hline & & & & & & & $R s s^{\mathrm{w}}$ & $\overline{\mathrm{Clk}^{\mathrm{x}}}$ & $\overline{\operatorname{Dec}^{y}}$ & 12889 & 13709 & $\overline{\text { OP97 }}$ & $\overline{1006}$ & 1007 \\
\hline $\mathrm{A}$ & 40 & 70 & 56 & 63 & 0 & 0 & 0 & 0 & 10 & 100 & 100 & 100 & 88 & 100 \\
\hline $\mathrm{AA}$ & 0 & 60 & 90 & 10 & 20 & 20 & 30 & 40 & 10 & 100 & 89 & 89 & 13 & 50 \\
\hline AAA & 70 & 50 & 50 & 50 & 50 & 0 & 40 & 10 & 0 & 100 & 89 & 100 & 50 & 38 \\
\hline $\mathrm{AAB}$ & 10 & 50 & 0 & 80 & 0 & 0 & 30 & 80 & 20 & 89 & 56 & 89 & 0 & 0 \\
\hline $\mathrm{AAC}$ & 80 & 20 & 30 & 50 & 0 & 0 & 20 & 30 & 0 & 100 & 78 & 100 & 63 & 75 \\
\hline AAD & 70 & 50 & 20 & 60 & 20 & 20 & 40 & 40 & 10 & 100 & 100 & 100 & 100 & 75 \\
\hline AAE & 20 & 50 & 50 & 100 & 10 & 0 & 40 & 0 & 0 & 100 & 100 & 100 & 88 & 88 \\
\hline $\mathrm{AAF}$ & 30 & 90 & 70 & 60 & 10 & 0 & 10 & 10 & 20 & 100 & 100 & 100 & 63 & 38 \\
\hline AAG & 0 & 80 & 20 & 40 & 30 & 0 & 10 & 0 & 30 & 67 & 78 & 67 & 50 & 38 \\
\hline AAJ & 50 & 60 & 60 & 30 & 10 & 20 & 0 & 20 & 0 & 100 & 100 & 100 & 63 & 75 \\
\hline AAK & 30 & 30 & 0 & 0 & 0 & 0 & 10 & 10 & 10 & 89 & 100 & 89 & 13 & 25 \\
\hline AAM & 30 & 80 & 50 & 10 & 10 & 0 & 0 & 50 & 20 & 100 & 89 & 100 & 75 & 25 \\
\hline AAN & 30 & 50 & 30 & 10 & 0 & 0 & 0 & 50 & 20 & 78 & 56 & 100 & 63 & 75 \\
\hline AAO & 60 & 60 & 50 & 30 & 0 & 10 & 0 & 10 & 40 & 100 & 100 & 100 & 63 & 63 \\
\hline AAP & 100 & 70 & 90 & 90 & 70 & 0 & 30 & 70 & 40 & 100 & 100 & 100 & 75 & 75 \\
\hline AAQ & 70 & 70 & 30 & 60 & 20 & 0 & 0 & 10 & 30 & 100 & 100 & 100 & 88 & 75 \\
\hline AAR & 50 & 80 & 10 & 20 & 20 & 0 & 40 & 30 & 20 & 89 & 89 & 100 & 25 & 13 \\
\hline AAU & 20 & 60 & 40 & 20 & 30 & 0 & 10 & 10 & 10 & 89 & 78 & 100 & 13 & 13 \\
\hline $\mathrm{AB}$ & 50 & 90 & 70 & 80 & 10 & 0 & 10 & 20 & 20 & 100 & 100 & 100 & 63 & 75 \\
\hline $\mathrm{AC}$ & 50 & 20 & 0 & 0 & 0 & 90 & 30 & 20 & 0 & 100 & 89 & 89 & 50 & 50 \\
\hline AD & 100 & 30 & 50 & 50 & 60 & 0 & 30 & 70 & 20 & 89 & 89 & 100 & 88 & 100 \\
\hline $\mathrm{AE}$ & 50 & 40 & 0 & 40 & 30 & 10 & 30 & 10 & 10 & 100 & 100 & 78 & 38 & 50 \\
\hline $\mathrm{AF}$ & 30 & 50 & 30 & 40 & 0 & 0 & 20 & 50 & 60 & 100 & 100 & 100 & 63 & 75 \\
\hline AG & 30 & 80 & 30 & 90 & 30 & 30 & 60 & 40 & 0 & 89 & 67 & 100 & 38 & 38 \\
\hline AI & 60 & 90 & 50 & 30 & 0 & 0 & 20 & 10 & 40 & 100 & 100 & 100 & 75 & 63 \\
\hline $\mathrm{AJ}$ & 80 & 60 & 50 & 60 & 30 & 60 & 40 & 10 & 0 & 78 & 89 & 89 & 88 & 75 \\
\hline $\mathrm{AK}$ & 90 & 60 & 20 & 50 & 40 & 0 & 10 & 0 & 30 & 100 & 89 & 100 & 50 & 50 \\
\hline AL & 100 & 60 & 30 & 60 & 30 & 10 & 10 & 20 & 40 & 78 & 67 & 100 & 88 & 38 \\
\hline AM & 70 & 80 & 50 & 100 & 30 & 50 & 50 & 0 & 10 & 100 & 100 & 100 & 63 & 100 \\
\hline AN & 80 & 60 & 40 & 70 & 70 & 20 & 40 & 0 & 40 & 100 & 100 & 100 & 63 & 63 \\
\hline $\mathrm{AO}$ & 50 & 40 & 60 & 90 & 40 & 0 & 10 & 40 & 0 & 100 & 100 & 100 & 25 & 25 \\
\hline AP & 0 & 70 & 100 & 20 & 40 & 0 & 50 & 40 & 20 & 100 & 100 & 100 & 63 & 38 \\
\hline AQ & 80 & 80 & 20 & 20 & 60 & 10 & 0 & 0 & 10 & 89 & 78 & 100 & 0 & 25 \\
\hline AR & 70 & 50 & 70 & 70 & 50 & 20 & 80 & 0 & 0 & 100 & 100 & 100 & 13 & 25 \\
\hline AS & 0 & 60 & 30 & 20 & 0 & 0 & 0 & 0 & 40 & 89 & 100 & 100 & 50 & 50 \\
\hline AT & 10 & 90 & 40 & 50 & 0 & 10 & 60 & 50 & 30 & 100 & 89 & 89 & 25 & 13 \\
\hline $\mathrm{AU}$ & 100 & 80 & 90 & 50 & 60 & 30 & 100 & 10 & 0 & 100 & 78 & 100 & 50 & 25 \\
\hline AV & 30 & 60 & 60 & 50 & 10 & 10 & 40 & 50 & 10 & 100 & 89 & 100 & 63 & 88 \\
\hline AW & 30 & 50 & 10 & 30 & 10 & 10 & 30 & 0 & 0 & 78 & 100 & 78 & 25 & 50 \\
\hline $\mathrm{AX}$ & 40 & 80 & 70 & 60 & 60 & 20 & 50 & 0 & 10 & 100 & 89 & 100 & 0 & 38 \\
\hline AY & 70 & 60 & 50 & 30 & 30 & 0 & 20 & 10 & 0 & 89 & 100 & 100 & 50 & 63 \\
\hline $\mathrm{AZ}$ & 80 & 50 & 60 & 0 & 10 & 10 & 80 & 40 & 20 & 100 & 89 & 89 & 75 & 63 \\
\hline B & 50 & 60 & 50 & 40 & 50 & 10 & 0 & 0 & 30 & 89 & 100 & 100 & 63 & 88 \\
\hline $\mathrm{C}$ & 70 & 100 & 80 & 40 & 20 & 20 & 20 & 10 & 0 & 100 & 56 & 89 & 50 & 50 \\
\hline CM334 & 90 & 50 & 70 & 70 & 30 & 100 & 100 & 20 & 10 & 100 & 89 & 78 & 38 & 50 \\
\hline $\mathrm{D}$ & 100 & 100 & 100 & 90 & 90 & 20 & 10 & 50 & 10 & 100 & 100 & 100 & 25 & 100 \\
\hline $\mathrm{E}$ & 60 & 90 & 80 & 10 & 10 & 10 & 10 & 30 & 40 & 100 & 100 & 100 & 88 & 63 \\
\hline $\mathrm{EJ}^{\mathrm{z}}$ & 0 & 60 & 20 & 0 & 10 & 10 & 10 & 10 & 0 & 100 & 100 & 78 & 63 & 88 \\
\hline $\mathrm{F}$ & 40 & 70 & 0 & 100 & 10 & 0 & 20 & 50 & 30 & 100 & 100 & 100 & 38 & 88 \\
\hline $\mathrm{G}$ & 80 & 60 & 30 & 70 & 30 & 10 & 30 & 10 & 50 & 100 & 100 & 100 & 38 & 25 \\
\hline $\mathrm{H}$ & 70 & 60 & 0 & 10 & 29 & 0 & 10 & 29 & 0 & 100 & 100 & 100 & $\ldots$ & $\ldots$ \\
\hline I & 0 & 30 & 10 & 10 & 0 & 0 & 20 & 20 & 20 & 89 & 89 & 100 & 63 & 13 \\
\hline $\mathrm{J}$ & 0 & 10 & 0 & 20 & 10 & 0 & 60 & 20 & 0 & 100 & 100 & 85 & 38 & 63 \\
\hline $\mathrm{K}$ & 100 & 80 & 70 & 20 & 60 & 40 & 30 & 10 & 0 & 89 & 89 & 89 & 25 & 38 \\
\hline $\mathrm{L}$ & 50 & 50 & 10 & 10 & 20 & 0 & 20 & 20 & 0 & 100 & 89 & 100 & 50 & 75 \\
\hline M & 90 & 80 & 40 & 50 & 20 & 10 & 0 & 30 & 40 & 100 & 89 & 100 & 38 & 50 \\
\hline $\mathrm{N}$ & 100 & 40 & 90 & 90 & 90 & 0 & 0 & 20 & 50 & 67 & 89 & 100 & 100 & 50 \\
\hline $\mathrm{O}$ & 60 & 50 & 0 & 20 & 10 & 0 & 10 & 10 & 0 & 89 & 89 & 100 & 25 & 38 \\
\hline $\mathrm{P}$ & 30 & 50 & 30 & 0 & 20 & 0 & 0 & 30 & 10 & 100 & 100 & 100 & 50 & 50 \\
\hline $\mathrm{R}$ & 30 & 30 & 0 & 50 & 20 & 40 & 30 & 0 & 10 & 100 & 89 & 100 & 13 & 25 \\
\hline $\mathrm{S}$ & 70 & 50 & 30 & 30 & 40 & 0 & 10 & 20 & 40 & 100 & 100 & 100 & 50 & 50 \\
\hline $\mathrm{T}$ & 50 & 90 & 10 & 0 & 40 & 0 & 0 & 40 & 0 & 100 & 89 & 100 & 63 & 25 \\
\hline V & 30 & 60 & 70 & 30 & 10 & 30 & 60 & 20 & 0 & 100 & 78 & 100 & 63 & 38 \\
\hline$X$ & 10 & 50 & 10 & 50 & 20 & 0 & 10 & 10 & 0 & 100 & 89 & 100 & 25 & 25 \\
\hline $\mathrm{Z}$ & 50 & 50 & 40 & 0 & 10 & 0 & 20 & 0 & 10 & 78 & 67 & 100 & 13 & 13 \\
\hline
\end{tabular}

q Alternaria sp.

$\mathrm{r}$ Botrytis sp.

s Colletotrichum acutatum.

t Fusarium solani.

u F. oxysporum.

v Rhizopus oryzae.

${ }^{w} R$. stolonifera.

x Sclerotinia sclerotiorum isolated from Clarksville, MI.

y $S$. sclerotiorum isolated from Decatur, MI.

z Early Jalapeno. 
observed for disease incidence or disease threshold above the LOD threshold.

When inoculated with $P$. nicotianae (isolate 1007), the two pepper parents had little variation in disease incidence (50\% CM334 and 88\% Early Jalapeno). Four lines had a significantly higher likelihood of infection compared with the population mean based on odds ratios, whereas lines $\mathrm{Q}$ and $\mathrm{AAB}$ had a significantly lower likelihood of infection (Table 3). Lines A, D, AD, and AM had 100\% disease incidence when infected with P. nicotianae (1007), whereas line AAB did not become diseased (Table 2). The population mean was $50.6 \pm$ $25.7 \%$. The LOD threshold for disease incidence was determined to be $3.02(10 \%)$ and $3.32(5 \%)$. No QTL were observed for disease incidence or disease threshold above the LOD threshold.

When inoculated with $P$. capsici isolates, the two pepper parents varied in disease incidence among isolates (Table 2). When compared with the population average, only line AC was significantly more likely to be infected for isolate OP97. Three lines (T, AI, and AAB) had a significantly lower likelihood of infection compared with the population mean when inoculated with isolate 13709 . No lines were significantly different from the population average when inoculated with isolate 12889 . The population mean was $73 \pm 22.6,69.1 \pm 28.5$, and $81.8 \pm 22.8 \%$ for isolates 12889,13709 , and OP97, respectively. The LOD threshold for disease incidence was determined to be 2.91 $(10 \%)$ and $3.24(5 \%)$ for isolate $12889,3.05(10 \%)$ and $3.38(5 \%)$ for isolate OP97, and $2.76(10 \%)$ and $3.02(5 \%)$ for isolate 13709 . No significant QTL were identified, though small peaks were observed on chromosome 5 for all three isolates.

Correlations among pathogens were detected for disease incidence for most pathogens evaluated (Table 5). The Sclerotinia sp. (Clarksville isolate) had no correlation in disease incidence with any of the remaining pathogens (data not shown). C. acutatum resistance was correlated with resistance to the greatest number of other pathogens. Disease incidence among the three $P$. capsici isolates was strongly positively correlated $(r>0.5, P<0.0001)$. Disease incidence between the $P$. nicotianae isolates was strongly positively correlated $(r=0.5754, P<0.0001)$.

\section{DISCUSSION}

Incorporating disease resistance into cultivars is a continuous process as pathogens evolve and host resistance is overcome. CM334, widely used in breeding programs across the United States for its durable Phytophthora spp. and Potato virus $Y$ resistance, has no known resistance or susceptibility to other common pepper pathogens. In this study, we evaluated CM334, Early Jalapeno, and their $\mathrm{F}_{6}$ progeny for susceptibility to minor (Rhizopus, Colletotrichum, Fusarium, and Sclerotinia spp.) and major (Phytophthora, Botrytis, and Alternaria spp.) pepper fruit pathogens. Our data suggest that breeding with CM334 could result in enhanced susceptibility to Sclerotinia, Fusarium, Colletotrichum, Alternaria, and Botrytis spp. while incorporating resistance to Phytophthora spp.

Resistance to Sclerotinia stem rot (a minor disease in the United States) has been identified in pepper accessions, although no commercial cultivars with resistance have been documented (Yanar and Miller 2003). Sources of fruit rot resistance, which may be inherited independently from stem rot, has not been identified in wild, unadapted, or cultivated pepper. Although neither of the parents was particularly susceptible to Sclerotinia spp., our results identified a single QTL at the end of chromosome 11. This is the first report of a resistance QTL to Sclerotinia spp. in pepper. The low incidence in the population suggests that Sclerotinia spp. susceptibility should not be a concern when breeding with CM334 but may also be the result of the particular isolates used in this study. The identified QTL did not colocalize with other disease resistance QTL or fruit QTL, and was not correlated with disease susceptibility to the other pathogens evaluated in this study. Further

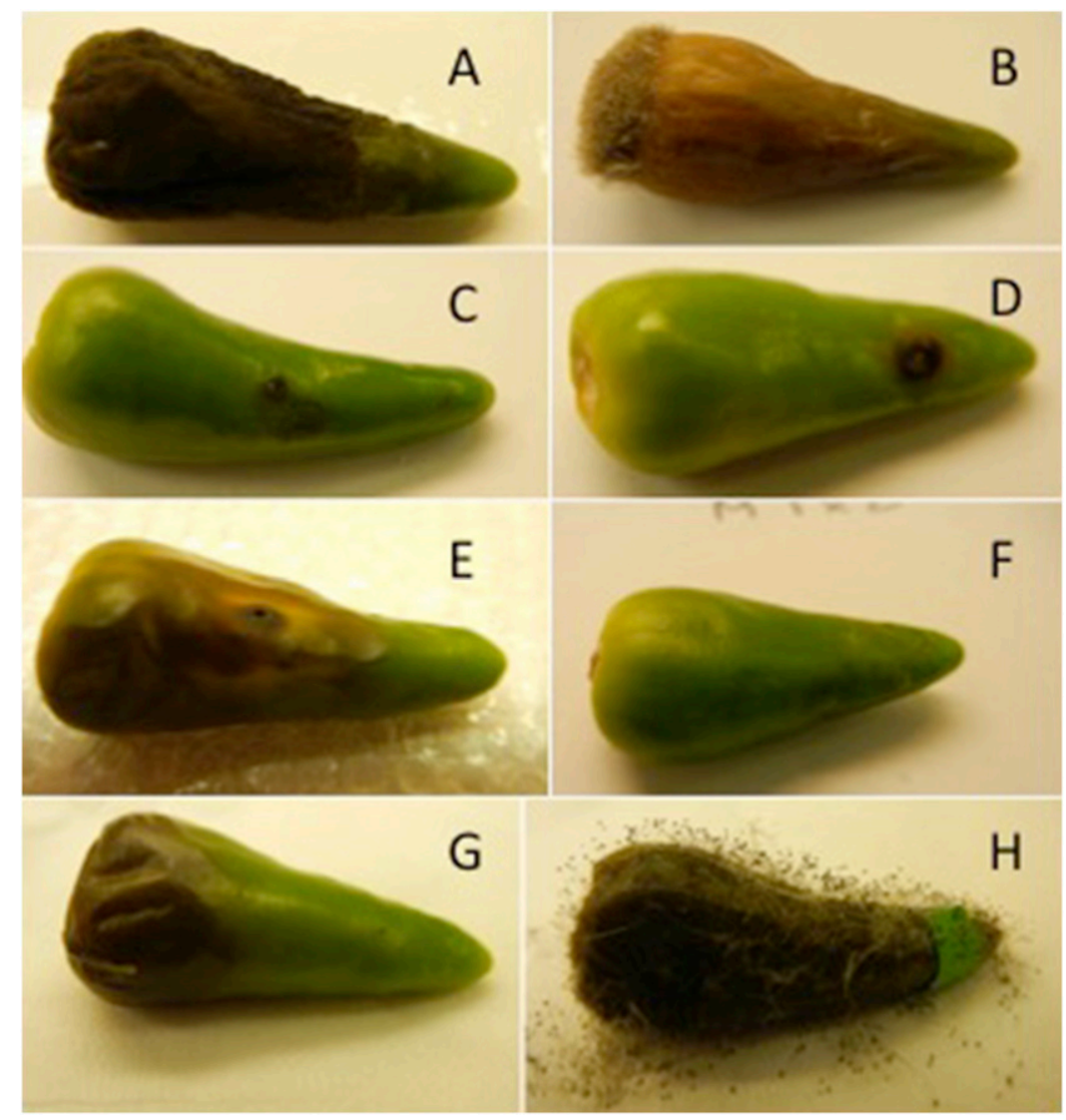

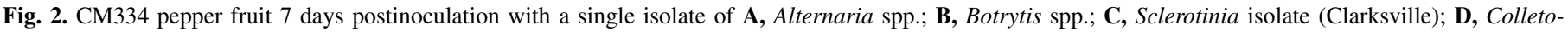
trichum acutatum; E, Sclerotinia isolate (Decatur); F, Fusarium oxysporum; G, F. solani; or $\mathbf{H}$, Rhizopus oryzae. 


\begin{tabular}{|c|c|c|c|c|c|c|c|c|c|c|c|c|c|c|}
\hline \multirow[b]{3}{*}{ Line } & \multirow[b]{3}{*}{$A l t^{\mathrm{q}}$} & \multirow[b]{3}{*}{$B o t^{r}$} & \multirow[b]{3}{*}{$\mathrm{Col}^{\mathrm{s}}$} & \multirow[b]{3}{*}{$F \cdot s^{\mathrm{t}}$} & \multirow[b]{3}{*}{ F. $o^{\mathrm{u}}$} & \multicolumn{4}{|c|}{ Pathogen } & & & & & \\
\hline & & & & & & & & Scle & ia sp. & & ohthora & & P. $n$ & anae \\
\hline & & & & & & $R s o^{\mathrm{v}}$ & $R s s^{\mathrm{w}}$ & $\mathrm{Clk}^{\mathrm{x}}$ & $\operatorname{Dec}^{y}$ & 12889 & 13709 & OP97 & 1006 & 1007 \\
\hline A & $\ldots$ & $\ldots$ & $\ldots$ & $\ldots$ & $\ldots$ & $\ldots$ & $\ldots$ & $\ldots$ & $\ldots$ & $\ldots$ & $\ldots$ & $\ldots$ & $\ldots$ & + \\
\hline AA & $\ldots$ & - & + & $\ldots$ & $\ldots$ & $\ldots$ & $\ldots$ & $\ldots$ & $\ldots$ & $\ldots$ & $\ldots$ & $\ldots$ & $\ldots$ & $\ldots$ \\
\hline AAA & $\ldots$ & $\ldots$ & $\ldots$ & $\ldots$ & $\ldots$ & $\ldots$ & $\ldots$ & $\ldots$ & $\ldots$ & $\ldots$ & $\ldots$ & $\ldots$ & $\ldots$ & $\ldots$ \\
\hline $\mathrm{AAB}$ & $\ldots$ & - & - & $\ldots$ & $\ldots$ & $\ldots$ & $\ldots$ & + & $\ldots$ & $\ldots$ & - & $\ldots$ & $\ldots$ & - \\
\hline AAC & - & $\ldots$ & $\ldots$ & $\ldots$ & $\ldots$ & $\ldots$ & $\ldots$ & $\ldots$ & $\ldots$ & $\ldots$ & $\ldots$ & $\ldots$ & $\ldots$ & $\ldots$ \\
\hline AAD & $\ldots$ & $\ldots$ & $\ldots$ & $\ldots$ & $\ldots$ & $\ldots$ & $\ldots$ & $\ldots$ & $\ldots$ & $\ldots$ & $\ldots$ & $\ldots$ & $\ldots$ & $\ldots$ \\
\hline AAE & $\ldots$ & $\ldots$ & $\ldots$ & + & $\ldots$ & $\ldots$ & $\ldots$ & $\ldots$ & $\ldots$ & $\ldots$ & $\ldots$ & $\ldots$ & $\ldots$ & $\ldots$ \\
\hline AAF & $\ldots$ & $\ldots$ & $\ldots$ & $\ldots$ & $\ldots$ & $\ldots$ & $\ldots$ & $\ldots$ & $\ldots$ & $\ldots$ & $\ldots$ & $\ldots$ & $\ldots$ & $\ldots$ \\
\hline AAG & $\ldots$ & - & $\ldots$ & $\ldots$ & $\ldots$ & $\ldots$ & $\ldots$ & $\ldots$ & $\ldots$ & $\ldots$ & $\ldots$ & $\ldots$ & $\ldots$ & $\ldots$ \\
\hline AAJ & $\ldots$ & $\ldots$ & $\ldots$ & $\ldots$ & $\ldots$ & $\ldots$ & $\ldots$ & $\ldots$ & $\ldots$ & $\ldots$ & $\ldots$ & $\ldots$ & $\ldots$ & $\ldots$ \\
\hline AAK & $\ldots$ & $\ldots$ & - & - & $\ldots$ & $\ldots$ & $\ldots$ & $\ldots$ & $\ldots$ & $\ldots$ & $\ldots$ & $\ldots$ & $\ldots$ & $\ldots$ \\
\hline AAM & $\ldots$ & $\ldots$ & $\ldots$ & $\ldots$ & $\ldots$ & $\ldots$ & $\ldots$ & $\ldots$ & $\ldots$ & $\ldots$ & $\ldots$ & $\ldots$ & $\ldots$ & $\ldots$ \\
\hline AAN & $\ldots$ & $\ldots$ & $\ldots$ & $\ldots$ & $\ldots$ & $\ldots$ & $\ldots$ & $\ldots$ & $\ldots$ & $\ldots$ & $\ldots$ & $\ldots$ & $\ldots$ & $\ldots$ \\
\hline $\mathrm{AAO}$ & $\ldots$ & $\ldots$ & $\ldots$ & $\ldots$ & $\ldots$ & $\ldots$ & $\ldots$ & $\ldots$ & $\ldots$ & $\ldots$ & $\ldots$ & $\ldots$ & $\ldots$ & $\ldots$ \\
\hline AAP & $\ldots$ & + & + & + & + & $\ldots$ & $\ldots$ & + & $\ldots$ & $\ldots$ & $\ldots$ & $\ldots$ & $\ldots$ & $\ldots$ \\
\hline AAQ & $\ldots$ & $\ldots$ & $\ldots$ & $\ldots$ & $\ldots$ & $\ldots$ & $\ldots$ & $\ldots$ & $\ldots$ & $\ldots$ & $\ldots$ & $\ldots$ & $\ldots$ & $\ldots$ \\
\hline AAR & $\ldots$ & $\ldots$ & $\ldots$ & $\ldots$ & $\ldots$ & $\ldots$ & $\ldots$ & $\ldots$ & $\ldots$ & $\ldots$ & $\ldots$ & $\ldots$ & $\ldots$ & $\ldots$ \\
\hline AAS & $\ldots$ & $\ldots$ & $\ldots$ & $\ldots$ & $\ldots$ & $\ldots$ & $\ldots$ & + & $\ldots$ & $\ldots$ & $\ldots$ & $\ldots$ & $\ldots$ & $\ldots$ \\
\hline AAU & $\ldots$ & $\ldots$ & $\ldots$ & $\ldots$ & $\ldots$ & $\ldots$ & $\ldots$ & $\ldots$ & $\ldots$ & $\ldots$ & $\ldots$ & $\ldots$ & $\ldots$ & $\ldots$ \\
\hline $\mathrm{AB}$ & $\ldots$ & $\ldots$ & $\ldots$ & $\ldots$ & $\ldots$ & $\ldots$ & $\ldots$ & $\ldots$ & $\ldots$ & $\ldots$ & $\ldots$ & $\ldots$ & $\ldots$ & $\ldots$ \\
\hline $\mathrm{AC}$ & $\ldots$ & $\ldots$ & - & - & $\ldots$ & + & $\ldots$ & $\ldots$ & $\ldots$ & $\ldots$ & $\ldots$ & $\ldots$ & $\ldots$ & $\ldots$ \\
\hline $\mathrm{AD}$ & + & $\ldots$ & $\ldots$ & $\ldots$ & + & $\ldots$ & $\ldots$ & + & $\ldots$ & $\ldots$ & $\ldots$ & $\ldots$ & $\ldots$ & + \\
\hline $\mathrm{AE}$ & $\ldots$ & $\ldots$ & - & $\ldots$ & $\ldots$ & $\ldots$ & $\ldots$ & $\ldots$ & $\ldots$ & $\ldots$ & $\ldots$ & $\ldots$ & $\ldots$ & $\ldots$ \\
\hline $\mathrm{AF}$ & $\ldots$ & $\ldots$ & $\ldots$ & $\ldots$ & $\ldots$ & $\ldots$ & $\ldots$ & $\ldots$ & + & $\ldots$ & $\ldots$ & $\ldots$ & $\ldots$ & $\ldots$ \\
\hline AG & $\ldots$ & $\ldots$ & $\ldots$ & + & $\ldots$ & $\ldots$ & + & $\ldots$ & $\ldots$ & $\ldots$ & $\ldots$ & $\ldots$ & $\ldots$ & $\ldots$ \\
\hline $\mathrm{AI}$ & $\ldots$ & $\ldots$ & $\ldots$ & $\ldots$ & $\ldots$ & $\ldots$ & $\ldots$ & $\ldots$ & $\ldots$ & $\ldots$ & - & $\ldots$ & $\ldots$ & $\ldots$ \\
\hline AJ & $\ldots$ & $\ldots$ & $\ldots$ & $\ldots$ & $\ldots$ & + & $\ldots$ & $\ldots$ & $\ldots$ & $\ldots$ & $\ldots$ & $\ldots$ & $\ldots$ & $\ldots$ \\
\hline AK & $\ldots$ & + & $\ldots$ & $\ldots$ & $\ldots$ & $\ldots$ & $\ldots$ & $\ldots$ & $\ldots$ & $\ldots$ & $\ldots$ & $\ldots$ & $\ldots$ & $\ldots$ \\
\hline $\mathrm{AL}$ & $\ldots$ & + & $\ldots$ & $\ldots$ & $\ldots$ & $\ldots$ & $\ldots$ & $\ldots$ & $\ldots$ & $\ldots$ & $\ldots$ & $\ldots$ & $\ldots$ & $\ldots$ \\
\hline $\mathrm{AM}$ & $\ldots$ & $\ldots$ & $\ldots$ & + & $\ldots$ & + & $\ldots$ & $\ldots$ & $\ldots$ & $\ldots$ & $\ldots$ & $\ldots$ & $\ldots$ & + \\
\hline $\mathrm{AN}$ & $\ldots$ & $\ldots$ & $\ldots$ & $\ldots$ & + & $\ldots$ & $\ldots$ & $\ldots$ & $\ldots$ & $\ldots$ & $\ldots$ & $\ldots$ & $\ldots$ & $\ldots$ \\
\hline $\mathrm{AO}$ & $\ldots$ & $\ldots$ & $\ldots$ & + & $\ldots$ & $\ldots$ & $\ldots$ & $\ldots$ & $\ldots$ & $\ldots$ & $\ldots$ & $\ldots$ & $\ldots$ & $\ldots$ \\
\hline $\mathrm{AP}$ & $\ldots$ & - & + & $\ldots$ & $\ldots$ & $\ldots$ & $\ldots$ & $\ldots$ & $\ldots$ & $\ldots$ & $\ldots$ & $\ldots$ & $\ldots$ & $\ldots$ \\
\hline AQ & $\ldots$ & $\ldots$ & $\ldots$ & $\ldots$ & + & $\ldots$ & $\ldots$ & $\ldots$ & $\ldots$ & $\ldots$ & $\ldots$ & $\ldots$ & $\ldots$ & $\ldots$ \\
\hline $\mathrm{AR}$ & $\ldots$ & $\ldots$ & $\ldots$ & $\ldots$ & $\ldots$ & $\ldots$ & + & $\ldots$ & $\ldots$ & $\ldots$ & $\ldots$ & $\ldots$ & $\ldots$ & $\ldots$ \\
\hline AS & $\ldots$ & - & $\ldots$ & $\ldots$ & $\ldots$ & $\ldots$ & $\ldots$ & $\ldots$ & $\ldots$ & $\ldots$ & $\ldots$ & $\ldots$ & $\ldots$ & $\ldots$ \\
\hline AT & $\ldots$ & - & $\ldots$ & $\ldots$ & $\ldots$ & $\ldots$ & + & $\ldots$ & $\ldots$ & $\ldots$ & $\ldots$ & $\ldots$ & $\ldots$ & $\ldots$ \\
\hline $\mathrm{AU}$ & $\ldots$ & + & + & $\ldots$ & $\ldots$ & $\ldots$ & + & $\ldots$ & $\ldots$ & $\ldots$ & $\ldots$ & $\ldots$ & $\ldots$ & $\ldots$ \\
\hline AV & $\ldots$ & $\ldots$ & $\ldots$ & $\ldots$ & $\ldots$ & $\ldots$ & $\ldots$ & $\ldots$ & $\ldots$ & $\ldots$ & $\ldots$ & $\ldots$ & $\ldots$ & $\ldots$ \\
\hline AW & $\ldots$ & $\ldots$ & $\ldots$ & $\ldots$ & $\ldots$ & $\ldots$ & $\ldots$ & $\ldots$ & $\ldots$ & $\ldots$ & $\ldots$ & $\ldots$ & $\ldots$ & $\ldots$ \\
\hline $\mathrm{AX}$ & $\ldots$ & $\ldots$ & $\ldots$ & $\ldots$ & $\ldots$ & $\ldots$ & $\ldots$ & $\ldots$ & $\ldots$ & $\ldots$ & $\ldots$ & $\ldots$ & $\ldots$ & $\ldots$ \\
\hline AY & $\ldots$ & $\ldots$ & $\ldots$ & $\ldots$ & $\ldots$ & $\ldots$ & $\ldots$ & $\ldots$ & $\ldots$ & $\ldots$ & $\ldots$ & $\ldots$ & $\ldots$ & $\ldots$ \\
\hline $\mathrm{AZ}$ & $\ldots$ & $\ldots$ & $\ldots$ & - & $\ldots$ & $\ldots$ & + & $\ldots$ & $\ldots$ & $\ldots$ & $\ldots$ & $\ldots$ & $\ldots$ & $\ldots$ \\
\hline B & $\ldots$ & $\ldots$ & $\ldots$ & $\ldots$ & $\ldots$ & $\ldots$ & $\ldots$ & $\ldots$ & $\ldots$ & $\ldots$ & $\ldots$ & $\ldots$ & $\ldots$ & $\ldots$ \\
\hline $\mathrm{C}$ & $\ldots$ & $\ldots$ & $\ldots$ & $\ldots$ & $\ldots$ & $\ldots$ & $\ldots$ & $\ldots$ & $\ldots$ & $\ldots$ & $\ldots$ & $\ldots$ & $\ldots$ & $\ldots$ \\
\hline CM334 & $\ldots$ & $\ldots$ & $\ldots$ & $\ldots$ & $\ldots$ & + & + & $\ldots$ & $\ldots$ & $\ldots$ & $\ldots$ & $\ldots$ & $\ldots$ & $\ldots$ \\
\hline $\mathrm{D}$ & $\ldots$ & + & + & + & + & $\ldots$ & $\ldots$ & $\ldots$ & $\ldots$ & $\ldots$ & $\ldots$ & $\ldots$ & $\ldots$ & + \\
\hline $\mathrm{E}$ & $\ldots$ & $\ldots$ & + & - & $\ldots$ & $\ldots$ & $\ldots$ & $\ldots$ & $\ldots$ & $\ldots$ & $\ldots$ & $\ldots$ & $\ldots$ & $\ldots$ \\
\hline $\mathrm{EJ}^{\mathrm{z}}$ & $\ldots$ & - & $\ldots$ & - & $\ldots$ & $\ldots$ & $\ldots$ & $\ldots$ & $\ldots$ & $\ldots$ & $\ldots$ & $\ldots$ & $\ldots$ & $\ldots$ \\
\hline $\mathrm{F}$ & $\ldots$ & $\ldots$ & $\ldots$ & + & $\ldots$ & $\ldots$ & $\ldots$ & $\ldots$ & $\ldots$ & $\ldots$ & $\ldots$ & $\ldots$ & $\ldots$ & $\ldots$ \\
\hline G & $\ldots$ & $\ldots$ & $\ldots$ & $\ldots$ & $\ldots$ & $\ldots$ & $\ldots$ & $\ldots$ & + & $\ldots$ & $\ldots$ & $\ldots$ & $\ldots$ & $\ldots$ \\
\hline $\mathrm{H}$ & $\ldots$ & $\ldots$ & - & $\ldots$ & $\ldots$ & $\ldots$ & $\ldots$ & $\ldots$ & $\ldots$ & $\ldots$ & $\ldots$ & $\ldots$ & $\ldots$ & $\ldots$ \\
\hline I & $\ldots$ & - & $\ldots$ & $\ldots$ & $\ldots$ & $\ldots$ & $\ldots$ & $\ldots$ & $\ldots$ & $\ldots$ & $\ldots$ & $\ldots$ & $\ldots$ & $\ldots$ \\
\hline $\mathrm{J}$ & - & - & - & $\ldots$ & $\ldots$ & $\ldots$ & + & $\ldots$ & $\ldots$ & $\ldots$ & $\ldots$ & $\ldots$ & $\ldots$ & $\ldots$ \\
\hline $\mathrm{K}$ & $\ldots$ & + & $\ldots$ & $\ldots$ & + & + & $\ldots$ & $\ldots$ & $\ldots$ & $\ldots$ & $\ldots$ & $\ldots$ & $\ldots$ & $\ldots$ \\
\hline $\mathrm{L}$ & $\ldots$ & $\ldots$ & - & $\ldots$ & $\ldots$ & $\ldots$ & $\ldots$ & $\ldots$ & $\ldots$ & $\ldots$ & $\ldots$ & $\ldots$ & $\ldots$ & $\ldots$ \\
\hline M & $\ldots$ & $\ldots$ & $\ldots$ & $\ldots$ & $\ldots$ & $\ldots$ & $\ldots$ & $\ldots$ & $\ldots$ & $\ldots$ & $\ldots$ & $\ldots$ & $\ldots$ & $\ldots$ \\
\hline $\mathrm{N}$ & $\ldots$ & + & + & + & + & $\ldots$ & $\ldots$ & $\ldots$ & + & $\ldots$ & $\ldots$ & $\ldots$ & + & $\ldots$ \\
\hline $\mathrm{O}$ & $\ldots$ & $\ldots$ & - & $\ldots$ & $\ldots$ & $\ldots$ & $\ldots$ & $\ldots$ & $\ldots$ & $\ldots$ & $\ldots$ & $\ldots$ & $\ldots$ & $\ldots$ \\
\hline P & $\ldots$ & $\ldots$ & $\ldots$ & - & $\ldots$ & $\ldots$ & $\ldots$ & $\ldots$ & $\ldots$ & $\ldots$ & $\ldots$ & $\ldots$ & $\ldots$ & $\ldots$ \\
\hline Q & $\ldots$ & $\ldots$ & $\ldots$ & $\ldots$ & $\ldots$ & + & $\ldots$ & $\ldots$ & $\ldots$ & $\ldots$ & $\ldots$ & $\ldots$ & $\ldots$ & - \\
\hline $\mathrm{R}$ & $\ldots$ & $\ldots$ & - & $\ldots$ & $\ldots$ & + & $\ldots$ & $\ldots$ & $\ldots$ & $\ldots$ & $\ldots$ & $\ldots$ & $\ldots$ & $\ldots$ \\
\hline S & $\ldots$ & $\ldots$ & $\ldots$ & $\ldots$ & $\ldots$ & $\ldots$ & $\ldots$ & $\ldots$ & $\ldots$ & $\ldots$ & $\ldots$ & $\ldots$ & $\ldots$ & $\ldots$ \\
\hline $\mathrm{T}$ & $\ldots$ & $\ldots$ & $\ldots$ & - & $\ldots$ & $\ldots$ & $\ldots$ & $\ldots$ & $\ldots$ & $\ldots$ & - & $\ldots$ & $\ldots$ & $\ldots$ \\
\hline V & $\ldots$ & $\ldots$ & $\ldots$ & $\ldots$ & $\ldots$ & $\ldots$ & $\ldots$ & $\ldots$ & $\ldots$ & $\ldots$ & $\ldots$ & $\ldots$ & $\ldots$ & $\ldots$ \\
\hline X & $\ldots$ & - & $\ldots$ & $\ldots$ & $\ldots$ & $\ldots$ & $\ldots$ & $\ldots$ & $\ldots$ & $\ldots$ & $\ldots$ & $\ldots$ & $\ldots$ & $\ldots$ \\
\hline $\mathrm{Z}$ & $\ldots$ & $\ldots$ & $\ldots$ & - & $\ldots$ & $\ldots$ & $\ldots$ & $\ldots$ & $\ldots$ & $\ldots$ & $\ldots$ & $\ldots$ & $\ldots$ & $\ldots$ \\
\hline
\end{tabular}

p Symbols indicate whether a line had significantly less (-) or more (+) likelihood of infection compared with the mean across lines for each pathogen. q Alternaria sp.

r Botrytis sp.

s Colletotrichum acutatum.

t Fusarium solani.

u F. oxysporum.

${ }^{\mathrm{v}}$ Rhizopus oryzae.

${ }^{\mathrm{w}} \mathrm{R}$. stolonifera.

x Sclerotinia sclerotiorum isolated from Clarksville, MI.

y $S$. sclerotiorum isolated from Decatur, MI.

z Early Jalapeno. 
research will need to be done to determine whether the identified QTL for fruit rot resistance corresponds to stem rot resistance. In other host-Sclerotinia spp. systems, studies have shown that isolatespecific interactions exist (Micic et al. 2005; Zhao and Meng 2002). Future QTL mapping studies should incorporate multiple isolates to ensure that general QTL are identified in addition to isolatespecific QTL.

Rhizopus spp. cause postharvest fruit rot on pepper and are considered opportunistic pathogens. The commercial parent (Early Jalapeno) was highly resistant to Rhizopus spp. and, due to the minor importance of the pathogen, one would expect most commercial cultivars to perform similarly. However, CM334 was highly susceptible to both Rhizopus spp. evaluated in this study. It should be noted that the population mean for disease incidence was low $(\leq 25 \%)$, suggesting that susceptibility to Rhizopus spp. is a recessive trait. Susceptibility to Rhizopus spp. was not correlated with any of the other pathogens evaluated in this study but susceptibility was strongly correlated between the two species. Due to the low incidence and lack of correlation with other diseases, Rhizopus fruit rot may not cause immediate problems when breeding $P$. capsici-resistant pepper but should be taken into consideration for downstream crosses. As with the Sclerotinia isolates evaluated in this study, the Rhizopus isolates collected from sugarbeet may have low virulence on pepper, which may have affected our results.

$P$. capsici is one of the major pathogens affecting solanaceous crops in the eastern United States. Chromosome 5 is the major QTL for $P$. capsici fruit, stem, and root rot resistance, and minor QTL have been identified on chromosomes 2, 3, 4, and 6 (Bonnet et al. 2007; Naegele et al. 2014; Ogundiwin et al. 2005; Sy et al. 2008). In this study, no significant QTL were identified for $P$. capsici resistance. The variation in $P$. capsici QTL is likely due, in part, to differences in

TABLE 4. Disease resistance quantitative trait loci (QTL) identified in an $\mathrm{F}_{6}$ Criollo de Morelos $\times$ Early Jalapeno pepper population

\begin{tabular}{llrrrl}
\hline Pathogen & Isolate & $\mathrm{Chr}^{\mathrm{x}}$ & $\operatorname{Pos}^{\mathrm{y}}$ & $R^{2 \mathrm{z}}$ & \multicolumn{1}{c}{ Data mapped } \\
\hline Alternaria sp. & $\ldots$ & 2 & 63 & $0.35^{* * *}$ & Threshold or incidence \\
Sclerotinia sp. & Decatur & 11 & 90 & $0.22^{*}$ & Incidence \\
\hline
\end{tabular}

${ }^{x}$ Chromosome.

y Centimorgan position on the chromosome.

z Significance of the QTL: * and $* * *$ indicate $P \leq 0.05$ and 0.001 , respectively. disease evaluations (qualitative versus quantitative). Qualitative variation in disease susceptibility was not observed, though quantitative variation (e.g., lesion size) was evident in some lines. Resistance to $P$. capsici was not correlated with resistance to any of the other pathogens evaluated, including $P$. nicotianae. This is in contrast with a previous study by Bonnet et al. (2007) in which QTL for resistance to $P$. nicotianaeinduced root rot overlapped with resistance for $P$. capsici-induced root rot. However, this may also be due, in part, to the low disease incidence by the $P$. nicotianae isolate.

Of all the pathogens evaluated, Alternaria spp. had the greatest number of correlations in susceptibility. Alternaria resistance from Early Jalapeno was detected within $5 \mathrm{cM}$ of a previously identified fruit shape QTL located in the same population on chromosome 2 (Naegele et al. 2014). This could indicate that Alternaria susceptibility in the CM334 background may be linked with the triangular fruit shape associated with 'Serrano' pepper (Naegele et al. 2014). In pepper, no studies are available; however, in tomato, QTL for resistance to $A$. solani have been identified on chromosomes $1,2,5$ to 7 , and 9 , explaining 9 to $16 \%$ of the variation observed (Chaerani et al. 2006). However, these studies were conducted with mixed isolates, and no information is available on Alternaria isolate-specific QTL in the family Solanaceae. More isolates will need to be evaluated to confirm the general usefulness of this QTL. Because susceptibility to Alternaria spp. was positively correlated with susceptibility to Colletotrichum spp., it is possible that resistance to these two pathogens are linked or controlled by overlapping pathways.

Previous studies have found that resistance to C. gloeosporioides and C. capsici is highly dependent on the isolate and the source of resistance. Most sources of anthracnose resistance are identified from Capsicum baccatum and $C$. chinense. Resistance to Colletotrichum acutatum was controlled by a dominant cluster on chromosome 5 from Capsicum chinense accession PBC932 (Sun et al. 2015; Voorrips et al. 2004). In $C$. annuum, resistance to Colletotrichum acutatum has not been previously evaluated. Although only one isolate of $C$. acutatum was evaluated in this study, it is important to note that CM334 was more susceptible than Early Jalapeno. Because no QTL were detected in this study, future research will be needed to determine the genomic location contributing to susceptibility. If resistance to C. acutatum does reside on chromosome 5, similar to previous studies (Sun et al. 2015), this could be particularly important, because chromosome 5 contains the major QTL for $P$. capsici resistance.

In our study, CM334 was highly susceptible to $F$. solani and resistant to F. oxysporum, whereas Early Jalapeno was resistant to both species.

TABLE 5. Pearson's correlation coefficient in disease incidence among pepper pathogens ${ }^{\mathrm{p}}$

\begin{tabular}{|c|c|c|c|c|c|c|c|c|c|c|c|c|c|}
\hline & \multirow[b]{2}{*}{$A l t^{\mathrm{r}}$} & \multirow[b]{2}{*}{$B o t^{\mathrm{s}}$} & \multirow[b]{2}{*}{$\mathrm{Col}^{\mathrm{t}}$} & \multirow[b]{2}{*}{ Fsol $^{\mathrm{u}}$} & \multirow[b]{2}{*}{ Foxy $^{\mathrm{v}}$} & \multirow[b]{2}{*}{$R s o^{\mathrm{w}}$} & \multirow[b]{2}{*}{$R s s^{\mathrm{x}}$} & \multicolumn{2}{|c|}{ Sclerotinia sp. } & \multicolumn{3}{|c|}{ Phytophthora capsici } & \multirow{2}{*}{$\frac{\text { P. nic }}{1006}$} \\
\hline & & & & & & & & Clark $^{y}$ & Decat $^{2}$ & $12889^{y}$ & 13709 & OP97 & \\
\hline Bot & 0.1320 & & $0.4360^{* * *}$ & 0.1621 & 0.1868 & -0.0420 & -0.0820 & 0.0090 & 0.1624 & -0.0557 & -0.0986 & -0.0896 & 0.0255 \\
\hline Col & $0.2981 *$ & $0.4360 * * *$ & & $0.2760^{*}$ & $0.4276 * * *$ & 0.1453 & 0.2394 & 0.0906 & 0.0872 & 0.1325 & $0.2965^{*}$ & $0.3249 * *$ & 0.2381 \\
\hline Fsol & $0.2958^{*}$ & 0.1621 & $0.2760 *$ & $\ldots$ & $0.3577 * *$ & 0.1172 & 0.2108 & 0.0934 & 0.1591 & -0.0207 & 0.1825 & 0.1343 & 0.1107 \\
\hline Foxy & $0.5756^{* * *}$ & 0.1868 & $0.4276^{* * *}$ & $0.3577 * *$ & $\ldots$ & 0.0933 & 0.1242 & -0.0297 & 0.0407 & 0.1027 & 0.1158 & 0.1847 & -0.04923 \\
\hline Rso & 0.2423 & -0.0420 & 0.1453 & 0.1172 & 0.0933 & $\ldots$ & $0.5014 * * *$ & -0.1524 & $-0.2672 *$ & -0.0391 & 0.1750 & -0.0983 & -0.0678 \\
\hline Rss & 0.0903 & -0.0820 & 0.2394 & 0.2108 & 0.1242 & $0.5014 * * *$ & $\ldots$ & 0.0437 & $-0.2661 *$ & -0.0661 & 0.1028 & -0.1036 & -0.1323 \\
\hline Clark & -0.0175 & 0.0090 & 0.0906 & 0.0934 & -0.0297 & -0.1524 & 0.0437 & $\ldots$ & 0.1581 & 0.0336 & -0.0117 & -0.1910 & 0.1107 \\
\hline Decat & 0.1359 & 0.1624 & 0.0872 & 0.1591 & 0.0407 & $-0.2672 *$ & $-0.2661 *$ & 0.1581 & $\ldots$ & 0.1461 & 0.0788 & 0.1983 & $0.2933^{*}$ \\
\hline 12889 & 0.0510 & -0.0557 & 0.1325 & -0.0207 & 0.1027 & -0.0391 & -0.0661 & 0.0336 & 0.1461 & $\ldots$ & $0.5998 * * *$ & $0.5396 * * *$ & 0.1994 \\
\hline 13709 & 0.1296 & -0.0986 & $0.2965^{*}$ & 0.1825 & 0.1158 & 0.1750 & 0.1028 & -0.0117 & 0.0788 & $0.5998 * * *$ & $\ldots$ & $0.6488 * * *$ & 0.2387 \\
\hline OP97 & 0.0828 & -0.0896 & $0.3249 * *$ & 0.1343 & 0.1847 & -0.0983 & -0.1036 & -0.1910 & 0.1983 & $0.5396 * * *$ & $0.6488^{* * *}$ & $\ldots$ & 0.2197 \\
\hline 1006 & 0.2349 & 0.0255 & 0.2381 & 0.1107 & -0.0493 & -0.0678 & -0.1323 & 0.1107 & $0.2933^{*}$ & 0.1994 & 0.2387 & 0.2197 & $\ldots$ \\
\hline $1007^{\mathrm{q}}$ & 0.2182 & 0.0109 & 0.2049 & $0.2566^{*}$ & 0.0268 & 0.0496 & -0.1230 & 0.0853 & 0.0633 & 0.0139 & $0.3059 *$ & 0.1458 & $0.5754 * * *$ \\
\hline
\end{tabular}

p Asterisks indicate significance at $0.05(*), 0.001(* *)$, or $\leq 0.0001(* * *)$.

q Phytophthora nicotianae.

$\mathrm{r}$ Alternaria spp.

s Botrytis spp.

t Colletotrichum acutatum.

u Fusarium solani.

v F. oxysporum.

${ }^{\mathrm{w}}$ Rhizopus oryzae.

${ }^{x} R$. stolonifera.

y Sclerotinia sclerotiorum isolated from Clarksville, MI.

z S. sclerotiorum isolated from Decatur, MI. 
No QTL were detected in the population for resistance to $F$. oxysporum or F. solani. However, quantitative studies may be more likely to identify genomic regions associated with resistance than this qualitative study. In a related species, tomato, as many as six genes have been identified as contributing to Fusarium resistance (Sela-Buurlage et al. 2001). This would suggest that Fusarium resistance in the Solanaceae family may have isolate-specific components, similar to results from a study conducted in bean (Park et al. 2001). F. solani, considered of minor importance in the United States, could become increasingly important as breeders incorporate Phytophthora resistance from CM334 into commercial cultivars. In pepper, resistance to $F$. oxysporum had not been previously mapped; this is likely due to the low occurrence of disease, as seen in this study.

Similarly, no QTL studies on $B$. cinerea have been performed in pepper but, in tomato, minor QTL (explaining $\leq 15 \%$ of the variation) were discovered for resistance to leaf and stem gray mold on chromosomes 1, 2, and 4 (Finkers et al. 2007b). Because neither parent demonstrated resistance to the pathogen, any resistant lines are likely due to recessive, epistatic combinations or pleiotropic effects.

In this study, the landrace parent (CM334) was not resistant to most of the pathogens evaluated, and was more susceptible than the cultivated parent in some instances. Early Jalapeno demonstrated resistance to Alternaria spp., C. acutatum, Rhizopus spp., and $F$. solani. Although no MDR sites were detected among the pathogens, several correlations in disease incidence were noted between pathogens. This suggests that future studies using quantitative data may be able to further identify QTL and sites of MDR. Although CM334 is a useful source of resistance to diseases caused by Phytophthora spp., evaluation of the resulting progeny is needed to ensure that disease susceptibility to other common pepper pathogens is not incorporated into the resulting cultivars.

\section{ACKNOWLEDGMENTS}

We thank our colleagues at Michigan State University (MSU) and Cornell University who provided isolates and lines for this research, including L. Hanson (MSU), J. Hao (University of Maine), E. Gachango (MSU), C. Smart (Cornell University), B. Harlan (MSU), P. Bosland (New Mexico State University), and L. Rodriguez-Salamanca (MSU); and M. Ahmad, H. Gutting, and J. Olsen for technical assistance.

\section{LITERATURE CITED}

Acquaah, G. 2012. Principles of Plant Genetics and Breeding. 2nd Ed. John Wiley \& Sons, Ltd., Chichester, UK.

Anand, T., Bhaskaran, R., Raguchander, T., Samiyappan, R., Prakasam, V., and Gopalakrishnan, C. 2009. Defense responses of chili fruits to Colletotrichum capsici and Alternaria alternata. Biol. Plant. 53:553.

Arahana, V. S., Graef, G. L., Specht, J. E., Steadman, J. R., and Eskridge, K. M. 2001. Identification of QTLs for resistance to in soybean. Crop Sci. 41:180-188

Bonnet, J., Danan, S., Boudet, C., Barchi, L., Sage-Palloix, A.-M., Caromel, B., Palloix, A., and Lefebvre, V. 2007. Are the polygenic architectures of resistance to Phytophthora capsici and P. parasitica independent in pepper? Theor. Appl. Genet. 115:253-264.

Broman, K. W., Wu, H., Sen, Ś., and Churchill, G. A. 2003. R/qtl: QTL mapping in experimental crosses. Bioinformatics 19:889-890.

Brouwer, D. J., Jones, E. S., and Clair, D. A. S. 2004. QTL analysis of quantitative resistance to Phytophthora infestans (late blight) in tomato and comparisons with potato. Genome 47:475-492.

Caranta, C., Lefebvre, V., and Palloix, A. 1997. Polygenic resistance of pepper to potyviruses consists of a combination of isolate-specific and broadspectrum quantitative trait loci. Mol. Plant-Microbe Interact. 10:872-878.

Chaerani, R., Smulders, M. J. M., van der Linden, C. G., Vosman, B., Stam, P., and Voorrips, R. E. 2006. QTL identification for early blight resistance (Alternaria solani) in a Solanum lycopersicum $\times S$. arcanum cross. Theor. Appl. Genet. 114:439-450.

Cheng, C. H. 2014. Inheritance of resistance to Pseudomonas syringae pv. actinidiae and genetic correlations with fruit characters in a diploid Actinidia chinensis (kiwifruit) population. Euphytica 198:305-315

Finkers, R., Bai, Y., van den Berg, P., van Berloo, R., Meijer-Dekens, F., Ten Have, A., van Kan, J., Lindhout, P., and van Heusden, A. W. 2007a.
Quantitative resistance to Botrytis cinerea from Solanum neorickii. Euphytica 159:83-92.

Finkers, R., van den Berg, P., van Berloo, R., ten Have, A., van Heusden, A. W., van Kan, J. A. L., and Lindhout, P. 2007b. Three QTLs for Botrytis cinerea resistance in tomato. Theor. Appl. Genet. 114:585-593..

Frans, M., Aerts, R., Laethem, S. V., and Ceusters, J. Environmental effects on growth and sporulation of Fusarium spp. causing internal fruit rot in bell pepper. Eur. J. Plant Pathol. In press. doi:10.1007/s10658-017-1235-4

Frary, A., Frary, A., Daunay, M. C., Huvenaars, K., Mank, R., and Doganlar, S. 2014. QTL hotspots in eggplant (Solanum melongena) detected with a high resolution map and CIM analysis. Euphytica 197:211-228..

Granke, L. L., Quesada-Ocampo, L. M., Lamour, K., and Hausbeck, M. 2012. Advances in research on Phytophthora capsici on vegetable crops in the United States. Plant Dis. 96:1588-1600.

Grube, R. C., Radwanski, E. R., and Jahn, M. 2000. Comparative genetics of disease resistance within the Solanaceae. Genetics 155:873-887.

Haggard, J. E., Johnson, E. B., and Clair, D. A. S. 2013. Linkage relationships among multiple QTL for horticultural traits and late blight (P. infestans) resistance on chromosome 5 introgressed from wild tomato Solanum habrochaites. G3 (Bethesda) 3:2131-2146.

Hibberd, A., and Gillespie, D. 1982. Heritability of field-resistance to bacterial leaf-spot disease in pepper (Capsicum annuum L). Sci. Hortic. (Amsterdam) 17:301-309.

Hibberd, A., Stall, R., and Bassett, M. 1987. Different phenotypes associated with incompatible races and resistance genes in bacterial spot disease of pepper. Plant Dis. 71:1075-1078.

Hill, T. A., Ashrafi, H., Reyes-Chin-Wo, S., Yao, J., Stoffel, K., Truco, M. J., Kozik, A., Michelmore, R. W., and Van Deynze, A. 2013. Characterization of Capsicum annuum genetic diversity and population structure based on parallel polymorphism discovery with a $30 \mathrm{~K}$ unigene pepper GeneChip. PLoS One 8:e56200.

Holdsworth, W. L., and Mazourek, M. 2015. Development of user-friendly markers for the pvrl and Bs3 disease resistance genes in pepper. Mol. Breed. 35:28.

Jo, Y. K., Barker, R., Pfender, W., Warnke, S., Sim, S. C., and Jung, G. 2008. Comparative analysis of multiple disease resistance in ryegrass and cereal crops. Theor. Appl. Genet. 117:531-543.

Kamara, A., El-Argawy, E., Korany, A. E., and Amer, G. 2016. Potential of certain cultivars and resistance inducers to control gray mould (Botrytis cinerea) of pepper (Capsicum annuиm L.). Am. J. Micro. Res. 10:1926-1937.

Khan, M. A., Olsen, K. M., Sovero, V., Kushad, M. M., and Korban, S. S. 2014. Fruit quality traits have played critical roles in domestication of the apple. Plant Genome 7. doi:10.3835/plantgenome2014.04.0018

Kim, S. H., Yoon, J. B., Do, J. W., and Park, H. G. 2008. A major recessive gene associated with anthracnose resistance to Colletotrichum capsici in chili pepper (Capsicum annuиm L.). Breed. Sci. 58:137-141.

Le, T. D., McDonald, G., Scott, E. S., and Able, A. J. 2013. Infection pathway of Botrytis cinerea in Capsicum fruit (Capsicum annuum L.). Aust. Plant Pathol. 42:449-459.

Mallard, S., Cantet, M., Massire, A., Bachellez, A., Ewert, S., and Lefebvre, V. 2013. A key QTL cluster is conserved among accessions and exhibits broad-spectrum resistance to Phytophthora capsici: A valuable locus for pepper breeding. Mol. Breed. 32:349-364.

Mestries, E., Gentzbittel, L., de Labrouhe, D. T., Nicolas, P., and Vear, F. 1998. Analyses of quantitative trait loci associated with resistance to shape Sclerotinia sclerotiorum in sunflowers (shape Helianthus annuus L.) using molecular markers. Mol. Breed. 4:215-226.

Micic, Z., Hahn, V., Bauer, E., Schön, C. C., and Melchinger, A. E. 2005. QTL mapping of resistance to Sclerotinia midstalk rot in RIL of sunflower population NDBLOSsel $\times$ CM625. Theor. Appl. Genet. 110:1490-1498.

Naegele, R., Hill, T., Ashrafi, H., Reyes Chin-Wo, S., Van Deynze, A., and Hausbeck, M. K. 2014. QTL mapping of fruit rot resistance to the plant pathogen Phytophthora capsici Leonian in a recombinant inbred line Capsicum annuum L. population. Phytopathology 104:479-483.

Ogundiwin, E. A., Berke, T. F., Massoudi, M., Black, L. L., Huestis, G., Choi, D., Lee, S., and Prince, J. P. 2005. Construction of 2 intraspecific linkage maps and identification of resistance QTLs for Phytophthora capsici rootrot and foliar-blight diseases of pepper (Capsicum annuиm L.). Genome 48: 698-711.

Padgett, G., Nutter, F., Kuhn, C., and All, J. 1990. Quantification of disease resistance that reduces the rate of tobacco etch virus epidemics in bell pepper. Phytopathology 80:451-455.

Park, S. O., Coyne, D. P., Steadman, J. R., and Skroch, P. W. 2001. Mapping of QTL for resistance to white mold disease in common bean. Crop Sci. 41: 1253-1262.

Pernezny, K., Roberts, P., Murphy, J., and Goldberg, N. 2003. Compendium of Pepper Diseases. American Phytopathological Society Press, St. Paul, MN.

Quirin, E. A., Mann, H., Meyer, R. S., Traini, A., Chiusano, M. L., Litt, A., and Bradeen, J. M. 2012. Evolutionary meta-analysis of solanaceous resistance 
gene and solanum resistance gene analog sequences and a practical framework for cross-species comparisons. Mol. Plant-Microbe Interact. 25:603-612.

R Development Core Team. 2012. R: A Language and Environment for Statistical Computing. Online publication. R Foundation for Statistical Computing, Vienna. https://www.r-project.org/

Rehrig, W. Z., Ashrafi, H., Hill, T., Prince, J., and Van Deynze, A. 2014. CaDMR1 cosegregates with QTL Pc5.1 for resistance to Phytophthora capsici in pepper (Capsicum annuum). Plant Genome 7.

Sela-Buurlage, M., Budai-Hadrian, O., Pan, Q., Carmel-Goren, L., Vunsch, R., Zamir, D., and Fluhr, R. 2001. Genome-wide dissection of Fusarium resistance in tomato reveals multiple complex loci. Mol. Genet. Genomics 265:1104-1111.

Singh, R., Giri, S. K., and Kotwaliwale, N. 2014. Shelf-life enhancement of green bell pepper (Capsicum аппиит L.) under active modified atmosphere storage. Food Packag. Shelf Life 1:101-112.

Sun, C., Mao, S. L., Zhang, Z. H., Palloix, A., Wang, L. H., and Zhang, B. X. 2015. Resistances to anthracnose (Colletotrichum acutatum) of Capsicum mature green and ripe fruit are controlled by a major dominant cluster of QTLs on chromosome P5. Sci. Hortic. (Amsterdam, Neth.) 181:81-88.

Sy, O., Steiner, R., and Bosland, P. W. 2008. Recombinant inbred line differential identifies race-specific resistance to Phytophthora root rot in Capsicum annuиm. Phytopathology 98:867-870.

Thabuis, A., Palloix, A., Pflieger, S., Daubeze, A. M., Caranta, C., and Lefebvre, V. 2003. Comparative mapping of Phytophthora resistance loci in pepper germplasm: Evidence for conserved resistance loci across Solanaceae and for a large genetic diversity. Theor. Appl. Genet. 106:1473-1485.

Tzortzakis, N., and Chrysargyris, A. 2017. Postharvest ozone application for the preservation of fruits and vegetables. Food Rev. Int. 33:270-315.

USDA Economic Research Service. 2017. Commodity Imports and Exports. https://www.ers.usda.gov/data-products/vegetables-and-pulses-data/bycommodity/

Voorrips, R. E., Finkers, R., Sanjaya, L., and Groenwold, R. 2004. QTL mapping of anthracnose (Colletotrichum spp.) resistance in a cross between Capsicum annuum and C. chinense. Theor. Appl. Genet. 109:1275-1282.

Walker, S. J., and Bosland, P. W. 1999. Inheritance of Phytophthora root rot and foliar blight resistance in pepper. J. Am. Soc. Hortic. Sci. 124:14-18.

Yanar, Y., and Miller, S. A. 2003. Resistance of pepper cultivars and accessions of Capsicum spp. to Sclerotinia sclerotiorum. Plant Dis. 87:303-307.

Zhao, J., and Meng, J. 2002. Genetic analysis of loci associated with partial resistance to Sclerotinia sclerotiorum in rapeseed (Brassica napus L.). Theor. Appl. Genet. 106:759-764.

Zitter, T. 2000. Vegetable MD: Pepper Disease Control. Online publication. http://vegetablemdonline.ppath.cornell.edu/NewsArticles/PepDisease Con.htm

Zwonitzer, J. C., Coles, N. D., Krakowsky, M. D., Arellano, C., Holland, J. B., McMullen, M. D., Pratt, R. C., and Balint-Kurti, P. J. 2010. Mapping resistance quantitative trait loci for three foliar diseases in a maize recombinant inbred line population-evidence for multiple disease resistance? Phytopathology 100:72-79. 